SPECIAL FEATURE: PREFACE

Energy Market Reform

\title{
Preface to the special feature on energy market reform
}

\section{Takashi Yanagawa ${ }^{1}$}

Published online: 6 December 2018

(c) Japan Economic Policy Association (JEPA) 2018

In accordance with the renewal of the International Journal of Economic Policy Studies (IJEPS), which is published by Springer-Nature from Vol. 13, it starts special features that deal with the current important policy issues. The first special feature, Energy Market Reform, is based on the plenary session of the International Conference of the Japan Economic Policy Association (JEPA) held in Okinawa, hosted by Ryukyu University, in 2017.

Professor Pepermans and Professor Kibune were the keynote speakers of the conference. Professor Nomura was a discussant of Professor Pepermans, but he contributed his original article to this special feature. All of the three articles are written for the researchers of economic policies of various areas to understand easily as well as those of energy economics, since the JEPA conference discusses the current policy issues from various points of view.

Energy market reform was preceded in Europe, and Japan is following Europe. Reviewing the experiences of energy market reform in Europe and Japan is helpful for all the nations in the world to consider the future energy market. The first article of Professor Pepermans, European energy market liberalization: experiences and challenges, evaluates the European energy reform, and recommends more competition in the retail market and the more physical market integration, which are also necessary in Japan. The second article of Professor Kibune, Regulatory reform of energy and economic growth in Japan, suggests that the market liberalization in Japan stimulated new entry and decreased investment in asset, which reduced the tariff. At the same time, the increase in renewable energy, introduced for decarbonated society, made the securing stable energy supply more difficult. The problem of stable supply through the introduction of renewable energy is a challenge in Europe, too, where the spread of renewable energy is going ahead of Japan. The third article of Professor Nomura, Security of electricity supply after liberalization: implications of the experience of UK market reform, examines securing stable energy supply in response to enlarged renewable energy usage in UK, and discusses widely from the development of capacity market to the possibility of utilization of electric cars.

Takashi Yanagawa

yanagawa@econ.kobe-u.ac.jp

1 Kobe University, Kobe, Japan 
As an official journal of the JEPA, the IJEPS will publish special features on hot policy debates, mainly based on plenary sessions at the JEPA international conferences. Please look forward to them.

Takashi Yanagawa

President of JEPA, and Co-editor of IJEPS 